\title{
Sachs' "Enterobacterium A12" Is an Aerogenic Variant of Shigella boydii 14
}

\author{
M. REGINA F. TOLEDO, ROSA M. SILVA, AND LUIZ R. TRABULSI \\ Department of Microbiology, Immunology and Parasitology, Escola Paulista de Medicina São Paulo, São \\ Paulo, Brazil
}

\begin{abstract}
We studied the biochemical relationships of "Enterobacterium A12" of Sachs to Shigella boydii 14 and Escherichia coli O32. "Enterobacterium A12" differed from typical strans of $S$. boydii 14 only in its ability to produce gas from glucose. Otherwise, "Enterobacterium A12" and $E$. coli $\mathrm{O} 32$ were biochemically quite different. On the basis of these findings we propose that "Enterobacterium A12" should be regarded as an aerogenic variant of $S$. boydii 14, analogous to the aerogenic varieties of Shigella flexneri 6.
\end{abstract}

In 1943 Sachs (9) described 10 strains of an aerogenic, mannitol-negative, enteric organism that he designated "Enterobacterium A12." Sachs thought that this organism was a possible member of the group of Shigella species which do not ferment mannitol. Subsequent studies of this organism led other workers to take different positions with regard to its classification. In 1950, Ewing and Hucks (4) concluded that the biochemical reactions of "Enterobacterium A12" were like those of Shigella and that the $\mathrm{O}$ antigens of this organism were identical to those of Escherichia coli 032. For this reason, these authors considered "Enterobacterium A12" to be an aberrant member of $E$. coli group O32. This concept was discussed further by Ewing and Hucks (5) in 1952. In 1961, Carpenter (1) showed that "Enterobacterium A12," $E$. coli O32, and Shigella boydii 14 had identical O antigens and that "Enterobacterium A12" and $S$. boydii 14 had the same biochemical pattern, except that "Enterobacterium A12" strains produced gas from glucose. These findings were confirmed by Szturm-Rubinsten et al. (13) in 1962. Based on these data and on the fact that Shigella flexneri 6 biovars can also be aerogenic $(2,3)$, these authors proposed that "Enterobacterium A12" should be regarded as an aerogenic biovar of $S$. boydii 14. However, in 1972 Edwards and Ewing (3) stated that the microrganisms designated by Sachs as "Enterobacterium A12" should not be regarded as possible members of the genus Shigella because they were aerogenic and utilized citrate mutatively in Christensen citrate agar medium and because some strains showed mutative fermentation of lactose.

As far as we know, no agreement has been reached with regard to the classification of "Enterobacterium A12" of Sachs. Accordingly, in
Bergey's Manual of Determinative Bacteriology, 8th ed. (2), $S$. boydii is defined as a group composed of only anaerogenic serovars.

In this paper we compare the biochemical characteristics and virulence properties of "Enterobacterium A12" and E. coli $\mathrm{O} 32$. We also suggest a modification in the definition of the genus Shigella in order to include aerogenic variants.

\section{MATERIALS AND METHODS}

Bacterial strains. We studied eight strains of "Enterobacterium A12" (T1-66 Pe, 28-67 SP, T-68 SP, T4$68 \mathrm{SP}, 1968-68 \mathrm{IAL}, 7-77 \mathrm{Pe}, 35-77 \mathrm{Pe}$, and 38001-79 LIAC), which were isolated from human feces in different areas of Brazil between 1966 and 1979. We also studied nine strains of $E$. coli $\mathrm{O} 32$; six of these strains (P6a, 5985-50 CDC, 3685-54 CDC, 6498-59 CDC, 1559$67 \mathrm{CDC}$, and 1913-72 CDC) were kindly provided by Betty R. Davis, Centers for Disease Control, Atlanta, Ga., and three strains (4-77 HC, 1191-77 CM, and 36$77 \mathrm{Pe}$ ) were freshly isolated strains identified in our laboratory.

Serological identification. Heated suspensions $\left(100^{\circ} \mathrm{C}, 1 \mathrm{~h}\right)$ of the eight "Enterobacterium A12" strains agglutinated to the titer of an S. boydii $14 \mathrm{O}$ antiserum $(1: 2,560)$. Furthermore, cross-absorption tests showed that the $\mathrm{O}$ antigens of "Enterobacterium A12" strain 35-77 Pe and S. boydii 14 were identical.

The serogroup of the $E$. coli $\mathrm{O} 32$ strains was determined by tube agglutination tests in $\mathrm{O}$ antiserum prepared with the standard strain of $E$. coli $\mathrm{O} 32$ (strain P6a). Slide agglutination tests were also performed with the same antiserum absorbed by the $O$ antigen of $E$. coli 083 , since this antiserum gave significant crossreactions with strains of this serogroup.

We used the methods recommended by Edwards and Ewing (3) for preparing the antisera and for performing the serological tests.

Biochemical tests. The $\beta$-galactosidase test was performed by the method of Lowe (7). All of the other tests were performed by using the methods recom- 
mended by Edwards and Ewing (3). However, the carbohydrate fermentation tests were observed for only 14 days.

Invasiveness assay. The ability of the strains to invade guinea pig eyes was tested by the method described by Serény (10). The "Enterobacterium A12" strains and the three $E$. coli 032 strains isolated in Brazil were tested within 1 week after isolation. The animals were observed for 7 days for evidence of keratoconjunctivitis.

\section{RESULTS}

Biochemical tests. The biochemical characteristics of the "Enterobacterium A12" and $E$. coli 032 strains tested are shown in Table 1. Table 1 also shows the biochemical pattern described by Ewing et al. (6) for 17 typical strains of $S$. boydii 14. This table shows that, with the exception of their ability to produce gas from glucose, the "Enterobacterium A12" strains could not be distinguished biochemically from typical strains of $S$. boydii 14. On the other hand, "Enterobacterium A12" and E. coli O32 strains had quite different biochemical patterns.

Invasiveness assay. All eight "Enterobacterium A12" strains yielded positive results in the Serény test. The keratoconjunctivitis which they caused was identical to that caused by the Shigella strains (10). None of the $E$. coli 032 strains (even the freshly isolated strains) gave positive results in this test.

\section{DISCUSSION}

The biochemical tests (Table 1) showed that "Enterobacterium A12" and E. coli O32 strains are quite different. Whereas all or the majority of the $E$. coli 032 strains tested gave positive results in the tests for production of indole and $\beta$-galactosidase, utilization of sodium acetate and mucate, motility, lysine decarboxylase, and fermentation of lactose, mannitol, salicin, rhamnose, and esculin, the "Enterobacterium A12" strains were negative in all these tests. On the other hand, the "Enterobacterium A12" strains differed from typical strains of S. boydii 14 only in their ability to produce gas from glucose. The inability of "Enterobacterium A12" strains to ferment mannitol no longer can be considered a difference between these strains and $S$. boydii 14 , since most anaerogenic $S$. boydii 14 strains do not ferment this substrate either (6). On the basis of these results, it seems clear that "Enterobacterium A12" strains are much more closely related to $S$. boydii 14 than to $E$. coli group O32. The mutative utilization of sodium citrate and lactose by "Enterobacterium A12" strains, which was detected by the method of Edwards and Ewing (3), was not included in our study
TABLE 1. Biochemical reactions of S. boydii 14, "Enterobacterium A12," and E. coli O32 ${ }^{a}$

\begin{tabular}{|c|c|c|c|}
\hline \multirow[b]{2}{*}{ Test } & \multicolumn{3}{|c|}{$\%$ of positive strains } \\
\hline & $\begin{array}{l}\text { S. boydii } \\
14^{b}\end{array}$ & $\begin{array}{c}\text { "Entero- } \\
\text { bacterium } \\
\text { A12" }\end{array}$ & E. coli $\mathrm{O} 32$ \\
\hline Indole (Kovacs) & 0 & 0 & 100 \\
\hline Methyl red & 100 & 100 & 100 \\
\hline Voges-Proskauer & 0 & 0 & 0 \\
\hline Christensen citrate & 0 & 0 & $0(11.1)^{c}$ \\
\hline Simmons citrate & 0 & 0 & 0 \\
\hline Sodium acetate & 0 & 0 & 77.8 \\
\hline Growth in KCN & 0 & 0 & 0 \\
\hline $\mathrm{H}_{2} \mathrm{~S}(\mathrm{TSI})^{d}$ & 0 & 0 & 0 \\
\hline Christensen urea & 0 & 0 & 0 \\
\hline Malonate & 0 & 0 & 0 \\
\hline Mucate & 0 & 0 & 88.9 \\
\hline Jordan tartrate & 0 & 0 & 44.4 \\
\hline $\begin{array}{l}\text { Phenylalanine deami- } \\
\text { nase }\end{array}$ & 0 & 0 & 0 \\
\hline Arginine dihydrolase & $7(93)$ & $37.5(62.5)$ & $0(55.6)$ \\
\hline Lysine decarboxylase & 0 & 0 & 66.7 \\
\hline $\begin{array}{l}\text { Ornithine decarboxyl- } \\
\text { ase }\end{array}$ & 0 & 0 & $22.2(22.2)$ \\
\hline Motility & 0 & 0 & 66.7 \\
\hline $\begin{array}{c}\beta \text {-Galactosidase }^{(\mathrm{ONPG})^{e}} \\
\end{array}$ & 0 & 0 & 100 \\
\hline Glucose (acid) & 100 & 100 & 100 \\
\hline Glucose (gas) & 0 & 100 & 88.9 \\
\hline Lactose & 0 & 0 & 100 \\
\hline Mannitol & 45 & 0 & 100 \\
\hline Sucrose & 0 & 0 & $22.2(11.1)$ \\
\hline Salicin & 0 & 0 & $55.6(44.4)$ \\
\hline Dulcitol & 0 & 0 & 44.4 \\
\hline Inositol & 0 & 0 & 0 \\
\hline Adonitol & 0 & 0 & 33.3 \\
\hline Raffinose & 0 & 0 & 33.3 \\
\hline Sorbitol & $60(40)$ & $75(25)$ & 100 \\
\hline Arabinose & 100 & 100 & 100 \\
\hline Rhamnose & 0 & 0 & 100 \\
\hline Xylose & $7(93)$ & $0(87.5)$ & 100 \\
\hline Trehalose & 100 & 100 & 100 \\
\hline Esculin & 0 & 0 & $55.6(33.3)$ \\
\hline Glycerol & $0(100)$ & $0(100)$ & 100 \\
\hline Cellobiose & 0 & 0 & 0 \\
\hline Erythritol & 0 & 0 & 0 \\
\hline Maltose & $27(73)$ & $12.5(87.5)$ & 100 \\
\hline
\end{tabular}

${ }^{a}$ We tested 8 "Enterobacterium A12" strains and 9 E. col O32 strains.

${ }^{b}$ Results of 17 S. boydii strains from Ewing et al. (6).

${ }^{c}$ Numbers in parentheses are percentages of positive strains after 3 or more days of incubation.

${ }^{d}$ TSI, Triple sugar iron agar.

e ONPG, 0 -Nitrophenyl- $\beta$-D-galactopyranoside.

since these tests have not been utilized recently as taxonomic criteria for enteric organisms.

If one considers that $S$. flexneri serovar 6 includes aerogenic biovars $(2,3)$, there is no reason for not accepting "Enterobacterium A12" as an aerogenic $S$. boydii 14 variant, as proposed by Carpenter (1) and Szturm-Rubinsten et al. (13). Furthermore, Rowe et al. (8) described an analogous situation for $S$. boydii 13 and concluded that the aerogenic variant could not be 
excluded from the genus Shigella by currently accepted criteria. A variant of Shigella dysenteriae 3 which produced gas from glucose was also described by Stypulkowska (12).

We suggest a modification in the definition of the genus Shigella to include strains that produce gas from fermentable carbohydrates but otherwise have typical Shigella characteristics. Aside from the academic aspect of this suggestion, there are some important practical considerations. For example, we (14) and probably other authors (15) have considered "Enterobacterium A12" strains as invasive $E$. coli $\mathrm{O} 32$ strains in order to be in agreement with the current definition of $S$. boydii, which states that this species is composed of only anaerogenic members $(2,3,6)$. Furthermore, according to several authors, the presence of gas in screening media, such as triple sugar iron agar and other media (3), should eliminate an enteric organism such as a Shigella unless the organism agglutinates in $S$. flexneri 6 antiserum $(2,3)$. It is possible that this recommendation has caused bacteriologists to miss aerogenic Shigella strains (other than $S$. flexneri 6) in routine diagnostic work or in epidemiological studies.

Very little is known about the geographic distribution of the aerogenic $S$. boydii 14 variant. However, this variant has also been isolated in other parts of the world (Betty R. Davis, Enteric Section, Centers for Disease Control, Atlanta, Ga., and Bernard Rowe, Salmonella and Shigella Reference Laboratory, Central Public Health Laboratory, London, England, personal communications). It is noteworthy that in Brazil we have not isolated the typical anaerogenic $S$. boydii 14.

The results of the Serény test show that "Enterobacterium A12" strains are invasive for guinea pig eyes, whereas $E$. coli $\mathrm{O} 32$ strains are not. Also, the biochemical reactions of $E$. coli O32 are different from those described for invasive $E$. coli strains $(11,14)$. Therefore, $E$. coli 032 must be regarded as a member of a typical noninvasive $E$. coli serogroup which has a somatic antigen identical to that of $S$. boydii 14 .

\section{ACKNOWLEDGMENTS}

We are grateful to Betty R. Davis and Bernard Rowe for their helpful advice. We are also indebted to Betty R. Davis for providing some of the cultures used in this study.

This work was supported by grants from the Fundação de Amparo à Pesquisa do Estado de São Paulo and Financiadora de Estudos e Projetos.

\section{REPRINT REQUESTS}

Address reprint requests to: Dr. M. Regina Toledo, Escola Paulista de Medicina, Disciplina de Microbiologia, Rua Botucatu 862-CEP 04023, São Paulo, Brazil.

\section{LITERATURE CITED}

1. Carpenter, K. P. 1961. The relationship of the Enterobacterium A12 (Sachs) to Shigella boydii 14. J. Gen. Microbiol. 26:535-542.

2. Cowan, S. T. 1974. Gram-negative facultatively anaerobic rods, p. 290-383. In R. E. Buchanan and N. E. Gibbons (ed.), Bergey's manual of determinative bacteriology, 8th ed. The Williams \& Wilkins Co., Baltimore.

3. Edwards, P. R., and W. H. Ewing. 1972. Identification of Enterobacteriaceae, 3rd ed. Burgess Publishing Co., Minneapolis.

4. Ewing, W. H., and M. C. Hucks. 1950. Two intermediate members of Enterobacteriaceae. J. Bacteriol. 60:367368.

5. Ewing, W. H., and M. C. Hucks. 1952. Four new provisional serotypes of Shigella. J. Immunol. 69:575-580.

6. Ewing, W. H., W. J. Martin, and J. E. Juagstetter. 1973. Shigella boydii, p. III-3. In Biochemical reactions of Shigella. Publication (CDC) 72-8081. Center for Disease Control, Atlanta, Ga.

7. Lowe, G. H. 1962. The rapid detection of lactose fermentation in paracolon organisms by the demonstration of $\beta$-D-galactosidase. J. Med. Lab. Technol. 19:21-25.

8. Rowe, B., R. J. Gross, and E. Van Oye. 1975. An organism differing from Shigella boydii 13 only in its ability to produce gas from glucose. Int. J. Syst. Bacteriol. 25:301-303.

9. Sachs, A. 1943. A report on an investigation into the characteristics of new types of non-mannitol-fermenting bacilli isolated from cases of bacillary dysentery in India and Egypt. J. R. Army Med. Corps 80:92-99.

10. Serény, B. 1955. Experimental Shigella keratoconjunctivitis. Acta Microbiol. Hung. 2:293-296.

11. Silva, R. M., M. R. F. Toledo, and L. R. Trabulsi. 1980. Biochemical and cultural characteristics of invasive Escherichia coli. J. Clin. Microbiol. 11:441-444.

12. Stypulkowska, H. 1964. An untypical strain of Shigella dysenteriae 3 isolated in Poland. Med. Dosw. Mikrobiol. 16:147-154.

13. Szturm-Rubinsten, S., D. Piéchaud, and G. Allos. 1962. A propos d'une variété gazogène de Shigella boydii 14. Ann. Inst. Pasteur Paris 103:303-305.

14. Trabulsi, L. R., M. R. F. Toledo, and M. E. Zuliani. 1967. Novas bactérias patogênicas para o intestino do homen. Rev. Inst. Med. Trop. São Paulo 9:31-39.

15. Vörös, S., B. Rédey, and F. Csizmazia. 1964. Antigenic structure of a new enteropathogenic $E$. coli strain. Acta Microbiol. Acad. Sci. Hung. 11:125-129. 